\title{
IbM Millenial Cerdas Keuangan bagi Siswa SMKN 1 di Kabupaten Aceh Timur
}

\author{
Muhammad Jamil ${ }^{1}$, Jamali ${ }^{2 *}$, Teuku Muana Refi ${ }^{3}$, Erni Wiriani ${ }^{4}$, Abdul Aziz ${ }^{5}$ \\ 1,23,4 Program Studi Keuangan dan Perbankan, Fakultas Ekonomi, Akademi Keuangan Perbankan \\ Nusantara, Jl. Medan-Banda Aceh, Kabupaten Aceh Timur, Indonesia \\ Corresponding Email: jamali@akubanknusantara.ac.id ${ }^{2}$.
}

\section{Article History:}

Received: Jun 2th 2021

Revised: Aug 11th 2021

Accepted: Sept 17th 2021

Keywords: Science and Technology for Society; Millennials; Intelligent; Finance; Student.
Abstract: The purpose of this activity is to train students to understand the principles as well as financial planning and management. The hope is that students can be responsible for their pocket money, be able to control themselves, and don't prioritize unimportant needs. In addition, students can also understand the concept of a simple business recording system as the simplest and most efficient business financial recording technique for small business plans. Through this training, participants are expected to be able to apply and develop it. The method of implementing service activities consists of 3 stages, namely; 1) Observation, 2) Seminar and Training, and 3) Evaluation and Reflection. This Community Service Implementation Activity was carried out from early January 2020 to March 2020. 1. The results of this community service activity showed that the students looked very enthusiastic in following the material provided by the instructors, where the students had a great curiosity. For each material provided, the training provided is very helpful for students in understanding simple bookkeeping and financial records, as well as the establishment of partnerships and collaborations between the Nusantara Banking Finance Academy, East Aceh Regency, and SMKN 1 Idi, East Aceh Regency. 


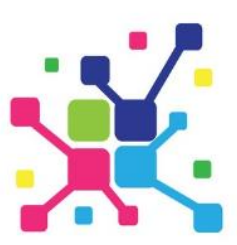

\section{Pendahuluan}

Setiap individu selalu memiliki kegiatan untuk mengelola keuangan berdasarkan kebutuhan masing-masing, dengan kemampuan yang dimiliki dapat mampu mengelola keuangan pribadi secara optimal. Hal tersebut juga dilakukan pada setiap instansi atau lembaga baik pendidikan maupun non-pendidikan sangat perlu dilakukan untuk mengatur aktivitas kinerja [1,2]. Pengelolaan dalam lembaga pendidikan meliputi banyak aspek, salah satunya yaitu pengelolaan keuangan $[3,4,5]$. Pengelolaan keuangan adalah perencanaan, pengarahan, pemantauan, pengorganisasian, dan pengendalian sumber daya moneter dari sebuah organisasi yang efisien dan efektif untuk mencapai tujuan organisasi [7,8,9]. Pencatatan adalah setiap transaksi dari suatu kegiatan usaha merupakan suatu informasi awal yang harus dicatat dan diolah [10], sehingga terbentuk sebuah laporan keuangan [11,12]. Pembukuan adalah suatu proses pencatatan yang dilakukan secara teratur untuk mengumpulkan data dan informasi keuangan yang meliputi harta, kewajiban, modal, penghasilan dan biaya, serta harga perolehan dan penyerahan barang atau jasa, yang ditutup dengan menyusun laporan keuangan berupa neraca, dan laporan laba rugi untuk periode Tahun Pajak tersebut $[10,13]$. Tujuan dari pencatatan dan pembukuan sederhana adalah agar dapat mempermudah suatu keluarga dalam mengelola keuangan keluarga sehingga dapat direncanakan dengan sebaikbaiknya [10,11]. Selain itu untuk mengkalkulasi, mengkontrol serta mengatur keseluruhan transaksi keuangan yang terjadi sepanjang keberlangsungan dunia usahanya $[11,14]$.

Penyusunan laporan keuangan mengikuti perkembangan Teknologi Informasi dan Komunikasi (TIK) di era digital saat ini $[15,16]$. Ketersediaan berbagai fitur dan formula rumus yang disajikan dalam bentuk lembar kerja pada aplikasi yang tersedia di playstore maupun AppStore dapat membantu penyelesaian proses siklus akuntansi $[17,18]$. Akan tetapi, pemahaman dalam mengelola keuangan pribadi menjadi sangat penting untuk membentuk karakter dan pengetahuan dalam pencatatan keuangan sederhana bagi siswa [19, 20]. Siswa SMKN 1 Idi di Kabupaten Aceh Timur selalu aktif dalam melakukan kegiatan bisnis untuk membantu pemahaman mereka dalam kegiatan yang diberikan di kelas. Kegiatan yang mereka erat kaitannya dengan kegiatan bisnis, oleh karenannya diperlukan penambahan ilmu tentang pembukuan dan pencatatan untuk mendukung kegiatan bisnis atau usaha mereka, dimana apabila sejak dini sudah diajarkan kelak usaha UMKM yang mereka rintis dapat berhasil dan maju.

Tujuan kegiatan ini adalah untuk melatih siswa untuk memahami prinsip serta perencanaan dan pengelolaan keuangan. Harapannya siswa dapat bertanggungjawab terhadap uang sakunya, mampu mengontrol diri dalam penggunaan uang. Selain itu, siswa juga dapat memahami konsep sistem pencatatan usaha sederhana sebagai teknik pencatatan keuangan yang paling sederhana dan efisien bagi rencana usaha kecil. Melalui pelatihan tersebut, peserta diharapkan dapat menerapkan dan mengembangkannya. 


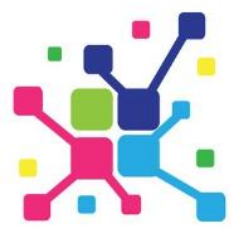

A J A D

Jurnal Pengabdian kepada Masyarakat

Vol. 1, No. 2, October, 2021, pp. 77-84 DOI : https://doi.org/10.35870/ajad.v1i2.16

\section{Metode}

a. Metode Pelaksanaan Kegiatan

Metode pelaksanaan kegiatan pengabdian terdiri dari 3 tahapan yaitu; 1) Observasi, 2) Seminar dan Pelatihan, dan 3) Evaluasi dan Refleksi. Tahap awal dilakukan observasi dengan mengadakan pendekatan dengan perwakilan siswa di lingkungan SMK Kabupaten Aceh Timur. Disamping itu, UKM Siswa dan Guru juga terlibat secara aktif dalam proses pengelolaan keuangan yang dilakukan pada Koperasi SMK Kabupaten Aceh Timur dan setiap anggota juga dilibatkan dalam kegiatan ini. Pada tahap kedua, dilakukan kegiatan pelatihan dan seminar mengenai konsep aset dan kewajiban, konsep nilai waktu dari uang, konsep resiko dalam keuangan, mengenal kepentingan dan karakter pribadi dalam keuangan, pelatihan dalam menentukan strategi keuangan dalam membuat keputusan. Dalam hal ini menyusun perencanaan keuangan pribadi. Pada tahap akhir, dilakukannya evaluasi dan refleksi mengenai keberhasilan kegiatan yang dilakukan. Hal ini ditempuh dengan cara menyebarkan kuesioner secara langsung apakah kegiatan ini dapat diterapkan secara maksimal dan dapat memberikan kebermanfaatan bagi siswa. Di akhir sesi peserta diminta untuk mengisi tes literasi keuangan dan menyusun perencanaan keuangan pribadi dengan simulasi kasus.

b. Waktu Efektif Pelaksanaan Kegiatan

Kegiatan Pelaksanaan Pengabdian Kepada Masyarakat ini dilakukan pada awal Januari 2020 sampai dengan Maret 2020.

c. Tempat Kegiatan

Lokasi pengabdian ini dilaksanakan pada ruang SMKN 1 Idi Kabupaten Aceh Timur.

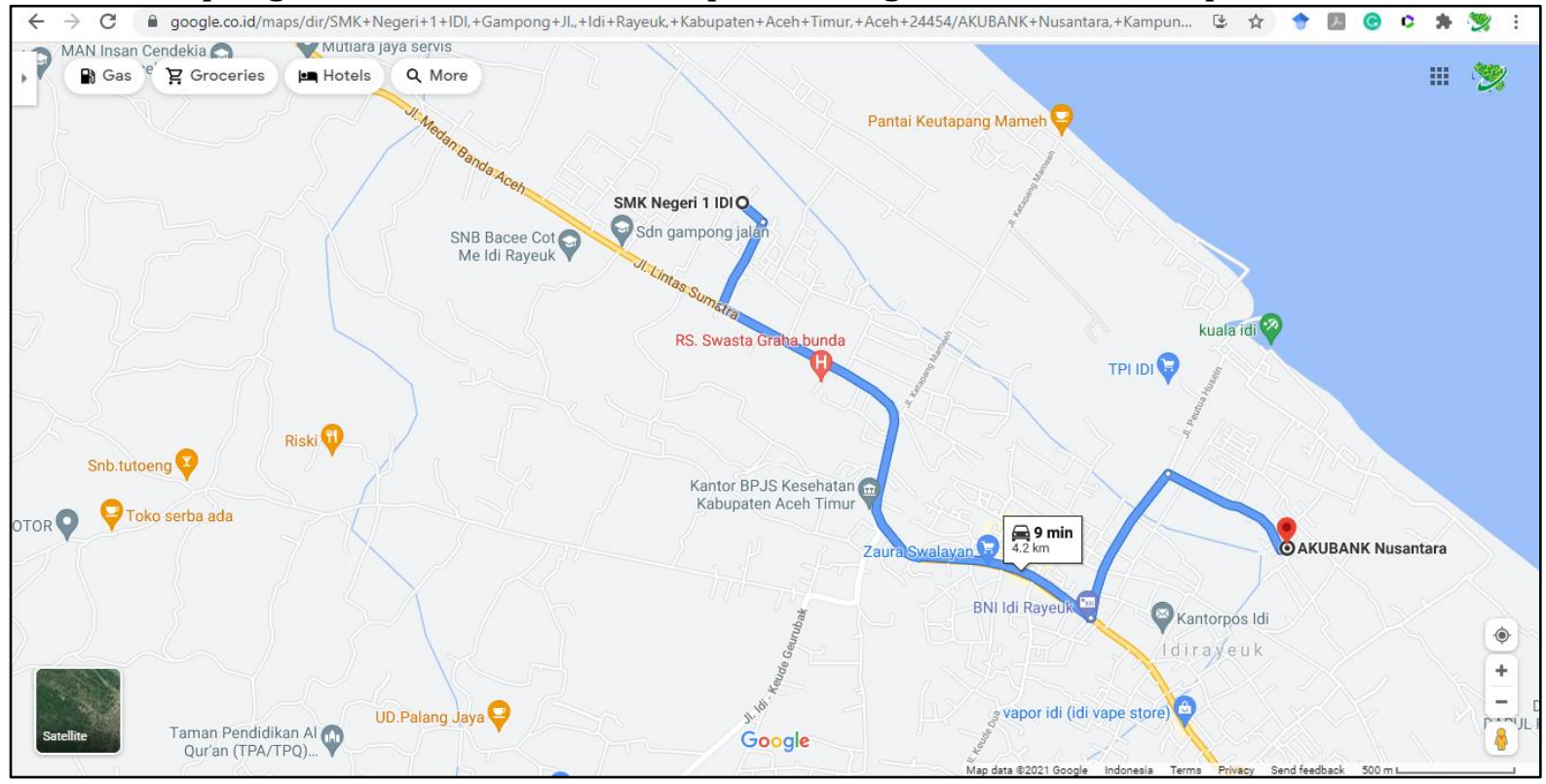

Gambar 1. Map Lokasi Kegiatan 


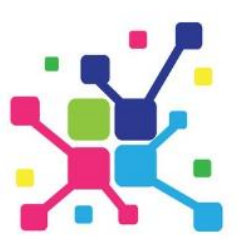

\section{Hasil}

Kegiatan observasi tim PKM ke SMKN 1 Idi Kabupaten Aceh Timur dilakukan pada awal bulan Januari yaitu pada tanggal 18 Januari 2020 oleh Tim Dosen Program Studi Keuangan dan Perbankan, Fakultas Ekonomi, Akademi Keuangan Perbankan Nusantara yang tergabung dalam Tim Pengabdian Kepada Masyarakat. Tim PKM disambut oleh Kepala Sekolah, Guru dan para siswa SMKN 1 Idi Kabupaten Aceh Timur. Pada pertemuan ini dilakukan pembicaraan awal dan perkenalan antara tim PKM. Tujuan diadakannya observasi awal adalah untuk menggali kembali persoalan serta kebutuhan para siswa dan siswi tentang pembukuan dan pencatatan keuangan sederhana.

Pada tahap selanjutnya, dilakukan kegiatan pelatihan dan seminar mengenai konsep aset dan kewajiban, konsep nilai waktu dari uang, konsep resiko dalam keuangan, mengenal kepentingan dan karakter pribadi dalam keuangan, pelatihan dalam menentukan strategi keuangan dalam membuat keputusan. Dalam hal ini menyusun perencanaan keuangan pribadi. Pada materi pertama, siswa diberikan kasus mengenai perbedaan antara aset dan kewajiban. Pada materi kedua, siswa diberikan pemahaman mengenai konsep nilai uang. Waktu adalah elemen yang penting bagi dunia keuangan terutama dalam hal pembuatan keputusan-keputusan yang berkaitan dengan keuangan. Konsep nilai waktu dari uang adalah konsep berkaitan dengan waktu dalam menghitung nilai uang. Pada materi ketiga, siswa diberikan pemahaman mengenai profil resiko dalam keuangan dengan mengenal karakter diri sendiri. Resiko keuangan merupakan sesuatu yang amat berhubungan dengan sifat manusia. Meskipun kita telah memahami statistik dan matematika tingkat atas namun jika mengabaikan elemen manusia maka dapat menimbulkan kegagalan dalam pengelolaan resiko keuangan. Terdapat dua pendekatan yang berbeda dalam menangani sebuah resiko keuangan. Pada materi keempat, siswa diberikan materi mengenai perencanaan keuangan pribadi. Dalam simulasi ini, siswa diberikan contoh kasus untuk menyusun anggaran keuangan pribadi. Hasil kegiatan tersebut siswa juga diberikan tes dengan menyelesaikan kasus yang diberikan beserta soal, rata-rata siswa telah menyusun dengan baik, Namun masih ada beberapa siswa yang tidak melakukan kegiatan menabung tetapi membeli barang-barang yang sifatnya konsumtif dan masih sedikit yang menyisihkan pengeluaran untuk melakukan kegiatan amal seperi sedekah, memberi orang tua, dan lainnya. Pada hasil tes keuangan yang digunakan disusun oleh tim pelaksana berdasarkan kajian teori dan hasil penelitian yang relevan. Hasil tes ini menunjukkan bahwa indeks pemahaman keuangan siswa terkategori cukup baik, dengan skor rata-rata 70. Kebanyakan siswa telah mampu membedakan konsep antara asset dan utang, melakukan perencanaan keuangan yang baik, dan konsep perhitungan bunga. Namun siswa masih lemah dalam hal mejawab konsep investasi baik itu dalam hal tabungan, deposito, asuransi, maupun pasar modal. Kelemahan ini bisa dimaklumi karena siswa yang non akuntansi, pemahaman konsep ini merupakan pengetahuan baru. 


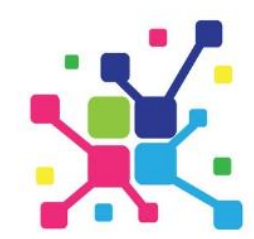

A J A D

Jurnal Pengabdian kepada Masyarakat

Vol. 1, No. 2, October, 2021, pp. 77-84 DOI : https://doi.org/10.35870/ajad.v1i2.16

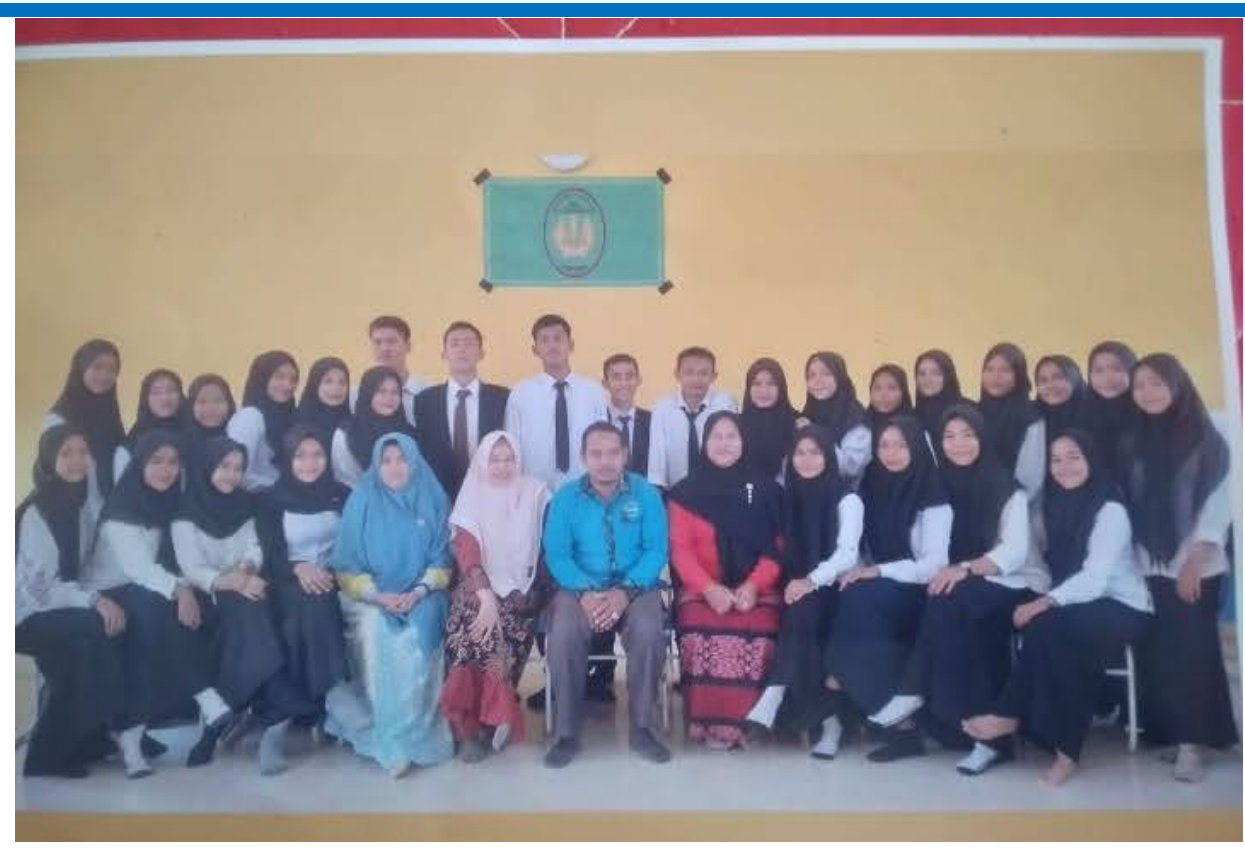

Gambar 2. Kegiatan Dokumentasi Setelah Kegiatan

Berdasarkan pengamatan dan evaluasi yang dilakukan selama pelatihan, dapat dilaporkan bahwa kegiatan PPM yang bertempat di ruang SMKN 1 Kabupaten Aceh Timur telah berhasil dilaksanakan dengan materi pelatihan yang dilaksanakan selama bulan Februari-Maret Bulan (10 Hari).

a. Faktor Pendukung

Faktor pendukung dalam melaksanakan program pelatihan ini adalah adanya dukungan dana dari pihak Akademi Keuangan Perbankan Nusantara Kabupaten Aceh Timur serta sudah adanya ruang pertemuan yang sudah dilengkapi dengan fasilitas seperti infocus dan peralatan pendukung lainnya.

b. Faktor Penghambat

Secara prinsip tidak ditemukan faktor penghambat yang berarti. Namun yang menjadi sedikit hambatan adalah jadwal pelaksanaan yang harus menyesuaikan dengan kesibukan dari tim PPM (dosen Akademi Keuangan Perbankan Nusantara) dan jadwal siswa dalam mempersiapkan ujian nasional.

c. Evaluasi

Sesi materi dalam pelaksanaannya berlangsung sangat baik. Minggu pertama, Peserta sangat antusias mengikuti kegiatan sampai akhir. Indikator lainnya adalah suasana terlihat hidup dengan adanya sesi tanya jawab dan diskusi di antara pelaksana PKM dengan siswa yang mengikuti kegiatan ini. Dan diketahui bahwa indeks pemahaman keuangan siswa terkategori cukup baik, dengan skor rata-rata 70 . 


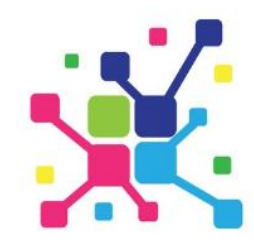

A J A D

Jurnal Pengabdian kepada Masyarakat

Vol. 1, No. 2, October, 2021, pp. 77-84

DOI : https://doi.org/10.35870/ajad.v1i2.16

\section{Kesimpulan}

1. Para Siswa dan siswi terlihat sangat antusias mengikuti materi yang diberikan oleh para instruktur.

2. Suasana pada saat pelatihan sangat aktif, dimana para siswa dan siswi memiliki keingintahuan yang begitu besar terhadap tiap materi yang diberikan.

3. Pelatihan yang diberikan sangat membantu para siswa dan siswi dalam memahami pembukuan dan pencatatan keuangan sederhana.

4. Para Siswa dan siswi yang sebelumnya belum terlalu paham pembukuan dan pencatatan keuangan sederhana mulai memahami manfaat dari pembukuan dan pencatatan keuangan sederhana.

5. Terjalin kemitraan dan kerjasama antara pihak Akademi Keuangan Perbankan Nusantara Kabupaten Aceh Timur dan SMKN 1 Idi Kabupaten Aceh Timur.

\section{Daftar Referensi}

[1] Sumendap, S., Koleangan, R.A. and Rotinsulu, T.0., 2021. STRATEGI PENGELOLAAN KEUANGAN UNIVERSTIAS SAM RATULANGI MANADO DI ERA BADAN LAYANAN UMUM. Jurnal Pembangunan Ekonomi dan Keuangan Daerah, 20(4), pp.26-39.

[2] Pandengkalu, R.P., Ratu, K., Sampetoding, E.A. and Manapa, E.S., 2021. Implementasi dan Sosialisasi Pengelolaan Daftar Hadir Siswa Di SMK Negeri 5 Talaud Kelas 12 RPL Secara Terkomputerisasi. Jurnal Pengabdian Nasional (JPN) Indonesia, 2(1), pp.6-12.

[3] Yushita, A.N., 2017. Pentingnya literasi keuangan bagi pengelolaan keuangan pribadi. Nominal: Barometer Riset Akuntansi dan Manajemen, 6(1), pp.11-26.

[4] Mudrifah, M. and Wisyastuti, A., 2021. Penguatan Karakteristik SDM dalam Implementasi Manajemen Berbasis Risiko di Lazis Muhammadiyah (LazisMu) Kabupaten Malang. Jurnal Pengabdian Nasional (JPN) Indonesia, 2(1), pp.19-27.

[5] Utama, D.A. and Setiyani, R., 2014. Pengaruh Transparansi, Akuntabilitas, Dan Responsibilitas Pengelolaan Keuangan Sekolah Terhadap Kinerja Guru. Dinamika Pendidikan, 9(2).

[6] Jaenudin, A., 2017, April. Analisis Pengelolaandan Pengawasan Keuangan Sekolah di SD Negeri Se-Kecamatan Waytuba". In Prosiding Seminar Pendidikan Ekonomi dan Bisnis (Vol. 3, No. 1).

[7] Iqbal, T., Mukhtar, M., Munawir, M., Syarifuddin, S. and Al-Bahri, F.P., 2020. IbM Sosialisasi Model Permainan untuk Pengembangan Sosial Emosional Anak. Jurnal Pengabdian Nasional (JPN) Indonesia, 1(1), pp.23-29. 


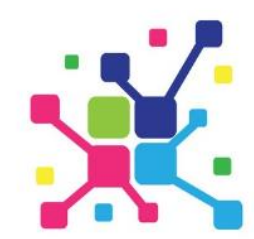

A J A D

Jurnal Pengabdian kepada Masyarakat

Vol. 1, No. 2, October, 2021, pp. 77-84

DOI : https://doi.org/10.35870/ajad.v1i2.16

[8] Sufyan, S. and Ahmad, L., 2020. Pelatihan Penyusunan Rencana Pembangunan Jangka Menengah Gampong (RPJMG) berbasis Masyarakat di Gampong Alue Naga Kecamatan Syiah Kuala Kota Banda Aceh. Jurnal Pengabdian Nasional (JPN) Indonesia, 1(2), pp.51-55.

[9] Idawati, I., Yuliana, Y., Rosalinda, M. and Kartini, K., 2020. Penyuluhan Kesehatan Tentang Pentingnya Program Keluarga Berencana di Desa Balee Ujong Rimba Kecamatan Mutiara Timur Kabupaten Pidie. Jurnal Pengabdian Nasional (JPN) Indonesia, 1(2), pp.56-62.

[10] Munandar, A., Meita, I. and Putritanti, L.R., 2018. Pelatihan Pembukuan Dan Pencatatan Keuangan Sederhana Kepada Siswa/I Yayasan Prima Unggul. Jurnal Pengabdian Kepada Masyarakat, 24(1), pp.527-532.

[11] Handayani, Kemas Vivi, Herry Suherman, Ryan Elfahmi, Hadyati Harras, and Agus Agus. "PELATIHAN PEMBUKUAN DAN PENCATATAN KEUANGAN SEDERHANA MENUJU ENTERPRENEUR MUDA YANG KREATIF DAN INNOVATIF KEPADA KARANG TARUNA RW 11 KELURAHAN PENGASINAN, KECAMATAN SAWANGAN, KOTA DEPOK." Jurnal Lokabmas Kreatif: Loyalitas Kreatifitas Abdi Masyarakat Kreatif 2, no. 1 (2021): 71-76.

[12] Hertati, L., Puspitawati, L., Gantino, R. and Ilyas, M., 2021. Makna Industri Kreatif Kearifan Lokal Kerajinan Limbah Pelepah Pinang Masyarakat Pinggiran Desa Mendis. Jurnal Pengabdian Nasional (JPN) Indonesia, 2(1), pp.28-35.

[13] Wulanditya, P., 2011. Kemudahan Penyajian Pajak Penghasilan (PPh) Bagi Pengusaha UKM dengan SAK ETAP. Pamator Journal, 4(2), pp.154-163.

[14] Ghaniy, W.U., 2018. Analisis Akuntansi Keuangan Usaha Mikro Kecil Dan Menengah Pada Rumah Makan Tembolok Medan (Doctoral dissertation).

[15] Hariyani, R., Utami, I.T., Retnoningrum, E. and Prasetio, T., 2020. Pelatihan Penyusunan Laporan Keuangan di Era Digital Melalui Perangkat Lunak Akuntansi Pada SMK Triguna 1956. IKRA-ITH ABDIMAS, 3(3), pp.176-182.

[16] Warsihna, J. and Warsihna, J., 2016. Meningkatkan literasi membaca dan menulis dengan teknologi informasi dan komunikasi (TIK). Jurnal Kwangsan, 4(2), pp.6780.

[17] Rizal, S. and Wali, M., 2018. Perbankan Komputer: Teori dan Praktikum. Deepublish.

[18] Ahmad, L., Sufyan, S. and Ahmad, A., 2020. Pelatihan Penggunaan Software Content Admission Sebagai Implementasi dari Konsep Complement Online Learning pada AMIK Indonesia. Jurnal Pengabdian Nasional (JPN) Indonesia, 1(2), pp.41-46. 
[19] Widyawati, I., 2012. Faktor-faktor yang mempengaruhi literasi finansial mahasiswa fakultas ekonomi dan bisnis Universitas Brawijaya. Assets: Jurnal Akuntansi dan Pendidikan, 1(1), pp.89-99.

[20] Putri, Y.A., 2017. PENGARUH PENGETAHUAN KEUANG AN DAN PENDIDIKAN KEUANGAN DI KELUARGA TERHADAP PENGELOLAAN KEUANGAN MAHASISWA DI SURABAYA (Doctoral dissertation, STIE PERBANAS SURABAYA). 